Вісник ЛНУ імені Тараса Шевченка № 1 (339), Ч. II, 2021

УДК 364.692:615.015.6:663.51]-053.67(477)

DOI: 10.12958/2227-2844-2021-1(339)-2-101-111

\title{
Трубавіна Ірина Миколаївна,
}

доктор педагогічних наук, професор, професор кафедри соціально-гуманітарних дисциплін

Національної академії Національної гвардії України,

м. Харків, Україна.

trubavina@gmail.com

https://orcid.org/0000-0003-1057-430X

\section{Каліна Катерина Євгеніївна,}

кандидат педагогічних наук, доцент, доцент кафедри педагогіки

Харківського національного педагогічного університету

імені Г. С. Сковороди, м. Харків, Україна.

kalinahnpu@gmail.com

https://orcid.org/0000-0002-4252-7690

\section{СОЦІАЛЬНА ПРОФІЛАКТИКА АЛКОГОЛІЗМУ СЕРЕД МОЛОДІ В УКРАЇНІ: ПЕРСПЕКТИВИ ТА РЕАЛІЇ СЬОГОДЕННЯ}

Проблема профілактики алкоголізму є актуальною багато часів. Оскільки алкоголізм - загроза здоров'ю і повноцінному життю теперішнього покоління, загроза життю майбутніх поколінь через спадковість і невиліковні хвороби. Алкоголь - певною мірою засіб зняття стресів. Але його негативні наслідки є більш вагомими в порівнянні 3 позитивними. Досліджуючи й аналізуючи етап існування сучасного українського суспільства 3 метою визначення проблем профілактики алкоголізму, пошуку шляхів їхнього вирішення, прогнозування, накреслення перспектив подальшого розвитку, науковці дійшли висновку, що поряд із зростанням активності кожного громадянина у соціальній, політичній сфері, новим поштовхам у науковій, художній та естетичній напрямах діяльності, чітко простежується підсилення негативних проявів i девіацій - злочинність, самогубство, насильство, жорстокість, аморальна поведінка, наркотична залежності. приводом для них часто $\epsilon$ саме алкоголь. На думку, В. Водніка, саме алкоголізм становить найбільшу соціальну та економічну небезпеку (Воднік, 2014). Досліджуючи проблему алкоголізму з соціального аспекту, Т. Котенко визначає, що споживання алкогольної продукції тісно пов'язано з психологічними особливостями особистості громадянина, неправильним розумінням сутності його впливу на людський організм (Котенко, 2014), бо досить поширеним є ставлення до алкоголю як до «ліків», «зігріваючого ефекту», засобу підняття настрою та позбавлення моральної незадоволеності чи емоційної втоми тощо. 


\section{Вісник ЛНУ імені Тараса Шевченка № 1 (339), Ч. II, 2021}

Відзначимо, що за рівнем поширеності алкоголізм займає третє місце після серцево-судинних i онкологічних захворювань у світі. Зазначимо, що це не нова хвороба, людство стикалося 3 нею протягом усього періоду свого існування. Про тяжкість і глобальність алкогольної залежності суспільства свідчить той факт, що протягом сторіч у різних країнах світу із нею боролися не тільки індивідуально, а й у державних масштабах («сухий закон», заборона продавати алкогольні напої після 23.00, заборона продавати алкогольні напої неповнолітнім). Таким чином, алкоголізм - це хвороба, яка $є$ глобальною. Важливим залишається і той факт, що ця хвороба має тенденцію до поширення й молодшає. Саме тому на сьогодні, коли українське суспільство має боротися з пандемією, долати спричинені нею труднощі, відновлюватись й протистояти, питання профілактики алкоголізму серед молоді стають ще більш актуальними й мають розроблятися не тільки теоретично, а й знаходити підтримку на державному, соціальному та освітньому рівнях. Мета статті полягає в обгрунтуванні резервів соціальної профілактики алкоголізму з дітьми та молоддю в Україні.

Як показав аналіз наукової літератури, широке коло питань щодо алкогольної залежності, методів боротьби і подолання, а також профілактики досліджено з точки зору медичної і психологічної наук. У медичних дослідженнях доведено, що зловживання алкоголю майже на чверть скорочує життя людини, а також знижує працездатність близько $17 \%$ і призводить до швидкої втомлюваності. Слід зазначити й статистичні дані: щороку в Україні від алкогольної хвороби помирає 40 тисяч громадян, більшість 3 яких становить молодь (Воднік, с. 245). Відповідно до статистичних даних ВОО3 Україна займає 5 місце (2012 р.) за споживанням алкоголю і 2 - за рівне смертності від алкоголю в Європі (Газета). Саме тому питання профілактики алкогольної залежності серед молоді, яка і становить майбутнє держави, на погляд авторів статті, має вивчатися більш глибоко саме в освітніх установах.

У підтримку зазначеного вище висновку зазначимо, що ВООЗ на Всесвітній асамблеї охорони здоров'я в Женеві було прийнято «Глобальну стратегію по зниженню зловживанням алкоголем», у якій зазначено необхідність проведення у закладах освіти профілактичних заходів та підтримка активного пропагування тверезості, дотримання здорового способу життя, активне залучення молоді до спорту, що матиме своїм наслідком формування конструктивного ставлення молоді до споживання алкогольної продукції.

Зрозумілим і незмінним залишається той факт, що профілактика алкоголізму матиме ефективність лише за умов масштабних соціальних, економічних, політичних, медичних, культурних i правових змін, спрямованих на вирішення проблеми алкогольної залежності суспільства.

Про глобальність і масштабність проблеми алкоголізму свідчать низка нормативно-правових документів, що була прийнята урядом 


\section{Вісник ЛНУ імені Тараса Шевченка № 1 (339), Ч. ІІ, 2021}

України з часів оголошення іï незалежною і суверенною державою. Серед них Конституція України, законодавство щодо охорони здоров'я, закони «Про захист прав споживачів», «Про державне регулювання виробництва i торгівлі спиртом етиловим, коньячним i плодовим, алкогольними напоями та тютюновими виробами», що були прийняті відповідно до положень Європейської хартії 3 алкоголю та Європейському плану боротьби 3 вживанням алкоголю (1995р.). На початку 2000 років Верховною Радою України були прийнято ряд положень щодо захисту суспільної моралі, боротьби 3 такими негативними явищами у суспільстві, як ВІЛ\СНІД, наркоманія та алкоголізм. Слід відзначити Закон України «Про внесення змін до деяких законодавчих актів щодо обмеження споживання i продажу пива та слабоалкогольних напоїв» (2010р.), головною метою якого $\epsilon$ підвищення культури споживання слабоалкогольних напоїв, профілактика алкоголізму серед молоді та стимулювання молоді до дотримання здорового способу життя. Також зазначимо, що вперше слабоалкогольній продукції було надано статус алкогольних напоїв, що обмежило рівень їхньої розповсюдженості серед молоді.

У ході наукового пошуку встановлено, що на території української держави 31996 року впроваджується Комплексна цільова програма боротьби зі злочинністю, у якій боротьбі з алкогольною залежністю відведено цілий розділ. Результатом реалізації програми стали: 1) підвищення якості медичної та соціальної антиалкогольної роботи, впровадження визнаних вітчизняних i світових лікувальнореабілітаційних програм; 2) посилення контролю за виконанням прийнятих законів щодо розповсюдження алкогольної продукції; 3) проведення профілактичних заходів щодо виявлення осіб, що зловживають алкоголем чи виготовляють його самостійно; 4) утворення просвітницьких центрів при наркологічних установах для отримання фахівцями 3 галузі освіти та соціальної діяльності навичок профілактичної діяльності тощо.

План заходів щодо реалізації зазначеної програми у 2015 році передбачав не тільки профілактику, контроль 3 боку держави, притягнення до відповідальності винних осіб, а й проведення й організацію заходів щодо виявлення осіб, які залучають неповнолітніх до противоправної діяльності, займаються продажем алкогольних напоїв неповнолітнім особам тощо.

На сьогодні питання профілактики алкоголізму в українському суспільстві набувають більшої необхідності. Про це свідчить прийняття Постанови кабінету міністрів України «Питання проведення моніторингу наркотичної та алкогольної ситуації в Україні» (2019р.), в якому до суб'єктів здійснення поряд з медичними, юридичними, адміністративним структурами включено МОН і Мінмолодьспорт, що свідчить про високий рівень ефективності проведення профілактичної діяльності щодо запобігання алкоголізму серед молоді у закладах освіти (Питання 


\section{Вісник ЛНУ імені Тараса Шевченка № 1 (339), Ч. II, 2021}

проведення моніторингу наркотичної та алкогольної ситуації в Україні, 2019). Анкетування передбачало отримання даних за такими джерелами: особисті дані, дані про заклад освіти, дані щодо отримання пропозиції спробувати, спроби вживання та вживання хоча б один раз, оточення, яке вживає, установ, у яких пропонували спробувати, рівня доступності придбання, частоти вживання та частоти пропозицій придбання, об'ємів та тривалості вживання, чинників, що призвели бо бажання спробувати алкогольні чи слабоалкогольні напої (Питання проведення моніторингу наркотичної та алкогольної ситуації в Україні, 2019).

Відповідно до Стратегії державної політики щодо наркотиків на період до 2020 року (Про схвалення Стратегії державної політики щодо наркотиків на період до 2020 року, 2013) саме профілактика вживання наркотиків i алкоголю дітьми i молоддю визначається пріоритетним напрямом соціальної політики держави, превенцією негативних проявів у поведінці, а також спрямовується запобігання зловживанню алкоголем. Відповідно до цього розпорядження визначено необхідність змістовного оновлення профілактичної роботи в суспільстві: формування захисних соціальних бар'єрів, готовності протистояти ризикам і негараздам без вживання алкогольної продукції; впровадження здорового способу життя i залучення молоді до суспільно корисної праці, розширення кола життєвих інтересів, не пов'язаних із вживанням алкоголю; взаємодія державних органів та інститутів громадянського суспільства із засобами масової інформації для підвищення рівня обізнаності населення щодо негативного впливу алкоголю на людський організм та сферу діяльності, надання об'єктивної, науково обгрунтованої інформації про небезпеки, пов'язані із вживанням алкоголю (Про схвалення Стратегії державної політики щодо наркотиків на період до 2020 року, 2013).

Найбільш ефективною формою профілактики алкоголізму відповідно до зазначеної вище Стратегії визначено селективну, що спрямована на запобігання залученню дітей i молоді, які внаслідок біологічних, психологічних або соціальних причин перебувають в обставинах, що спричиняють вживання алкогольних напоїв чи наркотиків (сім'ї, які перебувають у складних життєвих обставинах тощо). Провідним шляхом профілактики алкогольної залежності визначено впровадження апробованих передовою міжнародною та вітчизняною практикою профілактичних стратегій формування життєвих навичок, розроблення нових і удосконалення чинних програм та методик розв'язання алкогольних проблем згідно з вимогами МОН до наукових, науково-методичних та навчальних видань (Стратегія).

У результаті аналізу наукової літератури 3 проблеми, що вивчається, можливим стає формування найбільш загальних вимог до здійснення профілактичних заходів щодо подолання такого соціального явища, як алкогольна залежність серед української молоді. Ці вимоги становлять: 


\section{Вісник ЛНУ імені Тараса Шевченка № 1 (339), Ч. II, 2021}

- грунтовність, що передбачає об'єктивну оцінку й глибоке вивчення, аналіз інформації щодо заходів;

- конкретність у процесі визначення характеристики громадянина й застосування індивідуальних форм і методів профілактичної діяльності, а також чітке визначення терміну виконання;

- своєчасність, що полягає у виборі найбільш ефективних заходів впливу чи взаємодії між суб'єктами профілактичної роботи у конкретний період;

- реальність у плануванні і виконанні профілактичної діяльності, 3 урахуванням наявних можливостей для повноцінного виконання;

- повнота, що передбачає охоплення профілактичною діяльністю усіх сфер життєдіяльності особистості громадянина (Воднік, Профілактична діяльність...).

Як зазначено у роботах І. Данилюка, К. Каліної, С. Максименко, I. Трубавіної для успішної профілактичної діяльності необхідним $\epsilon$ врахування наступних аспектів: спрямованість на певний контингент i врахування його характеристик під час проведення профілактичної діяльності; врахування вікових, статевих і психологічних особливостей категорії громадян, для яких проводиться захід; визначення ефективності; надання конкретних рекомендацій щодо його проведення; можливість модифікації елементів профілактичної діяльності за необхідності (Максименко, 2005; Трубавіна\&Каліна, 2020).

Окреме місце серед профілактики алкоголізму посідає соціальна профілактика цього явища, яке належить до сфери соціальної роботи i передбачає заходи з боку соціальних служб, надання соціальних послуг сім'ям, дітям та молоді щодо обмеження використання ними алкоголю. Так, соціальна профілактика, відповідно до чинного законодавства в Україні про соціальну роботу, означає,що в сімейному, дитячому та молодіжному середовищі передбачено здійснення: комплексних заходів, спрямованих на запобігання сімейному неблагополуччю, соціальному сирітству, домашньому насильству та жорстокому поводженню 3 дітьми, торгівлі людьми, найгіршим формам дитячої праці;системного обліку і догляду за дітьми та молоддю, які виявили схильність до асоціальної поведінки; інформаційно-просвітницької, пропагандистської роботи в сім'ях, серед дітей та молоді за місцем проживання, навчання або роботи, спрямованої на формування в особистості стандартів позитивної поведінки, здорового способу життя (Закон України «Про соціальну роботу з сім'ями, дітьми та молоддю», 2001).

Таке розуміння соціальної профілактики, яка здійснюється на основі добровільності прийняття соціальних послуг в Україні в межах системного, соціально-виховного і середовищного підходів, кризового втручання i допомоги для самодопомоги, передбачає необхідність різноманітних заходів щодо соціальної профілактики алкоголізму - від роботи 3 особистістю, його сім'єю і мікросередовищем до роботи 3 макросередовищем, від дитини до дорослих, від наслідків девіантної 


\section{Вісник ЛНУ імені Тараса Шевченка № 1 (339), Ч. II, 2021}

поведінки до іï причин і приводів, всюди, де перебувають особи, які можуть бути схильні до алкоголізму. Враховуючи профілактичні заходи в країні і в світі, зауважимо, що соціальна профілактика алкоголізму частіше спрямована на роботу в середовищі на виявлення і обмеження цього явища, на просвітницьку роботу на 3 рівнях: первинну (масову) щодо інформування про негативні наслідки алкоголю; вторинну - щодо груп ризику з роботою щодо викоренення такої звички, якщо вона вже з'явилась, вміння відмови від алкоголю, заповнення дозвілля позитивним змістом, $з$ тими, хто вже мав справу з алкоголем і членами їх сімей, які вже від цього постраждали, для зменшення співзалежності; третинну для зменшення наслідків алкоголізму, формування стійкого бажання від нього відмовитися і навчання жити без нього.

Соціальна профілактика має своєю особливістю саме роботу в середовищі щодо просвіти про негативні наслідки алкоголізму і його ризики для поведінки і здоров'я теперішнього і майбутнього покоління. Відомо, що мікро- та макросередовища - визначальні фактори розвитку особистості поряд з активністю самої особистості. Тому показ позитивної моделі життєдіяльності в середовищі без алкоголізму, як в колонії А. Макаренка, де були режим, дисципліна, мажор, покарання та заохочення, відсутність вільного часу, система перспективних ліній життя колективу створює середовище, в якому немає місця негативним звичкам. Більш того, в такому середовищі формується нетерпимість до алкоголю і паління, наркоманії. Для формування звички потрібно від одного дня до 90 днів. Коли людина живе повноцінним реальним суспільним життям, яке приносить сенс і задоволення, вона не тягнеться до алкоголю. Але тут вникає питання про зміст соціальної профілактики в деталях. Як навчити жити без стресів і отримувати задоволення від життя і роботи, навчання, усунути перевантаження, фактори середовища типу пандемії коронавірусу тощо. Тому постає питання про те, що в сучасних умовах потрібно навчання не тільки позитивним моделям життя без алкоголізму, але й тому, як справлятися 3 труднощами, формувати в себе стресостійкість, вміти знижувати тривожність, вміти сказати «ні», бути впевненою людиною, якою не здатні маніпулювати інші, володіти собою тощо. Ці питання входять до життєвих умінь та навичок (Трубавіна, 2007), для формування яких потрібна активність самої людини і іiі бажання бути такою, що можливе в соціальних службах, превентивне виховання в закладах освіти, до якого включене питання превенції алкоголізму, чого зараз майже немає. Щодо життєвих умінь та навичок. Сьогодні ці питання $є$ основою роботи соціальних шкільних служб США, Великобританії, але не України. Життєві вміння формуються тільки на засадах добровільності в центрах соціальних служб для сім'ї, дітей та молоді, для тих, хто сам свідомо прийшов до них. Державної ж програми щодо формування життєвих умінь, як потрібні кожній особистості в житті, сьогодні в Україні, на жаль, немає. До життєвих умінь входять: комунікативні, вміння керувати своєю 


\section{Вісник ЛНУ імені Тараса Шевченка № 1 (339), Ч. II, 2021}

поведінкою і впливати на інших, вміння критичного мислення i прийняття рішень (Трубавіна, 2007). Саме ці життєві вміння є основою соціалізованої поведінки і приводять до свідомого вибору життя 3 алкоголем, насильством, наркоманією чи без них. Вони комплексно формують здорові звички поведінки особистості в будь-яких негативних умовах і повинні тому стати основою вторинної і третинної соціальної профілактики. Тому потрібна окрема програма в МОН щодо формування життєвих умінь 31 по 11 класи в учні поряд з батьківським лекторієм (просвітою) щодо профілактики алкоголізу у дітей і дорослих. Соціальні ж служби при цьому можуть працювати з тими, хто вирішив відмовитися від алкоголізму і членами їх сімей, щодо третинної профілактики алкоголізму. Первинну соціальну профілактику алкоголізму можуть здійснювати всі, хто має доступ до інформування молоді, дітей, дорослих як просвіту з проблему і соціальну рекламу установ, які вирішують проблему позбавлення від алкоголізму, якщо він вже $\epsilon$.

Зазначимо, що якщо людина не хоч позбавитися цією негативної звички, потрібна робота в третинній соціальній профілактиці щодо іiі мотивації до роботи над собою, створення умов для усунення негативних факторів, які приводять до алкоголізму (мікросередовище, макросередовище, спадковість тощо), і посилення позитивних факторів (превентивне виховання, навчання життєвим вмінням). Мотивувати людину до позбавлення такої негативної звички як алкоголізм можуть стимули і перспективи подальшого власного життя, майбутнє дітей, бажання зберегти сім'ю i роботу тощо. Позитивні результати за кордоном дають методики укріплення сім'ї, сімейно-орієнтована терапія, коли сім'ю вчать як допомагати члену родини подолати залежність, товариства анонімних алкоголіків, групи підтримки і взаємної підтримки сімей алкоголіків тощо. Головне питання - як не тільки допомогти людині позбавитися від негативної звички, а й допомогти ій знайти сенс подальшого життя, включити заново в родинне коло і спілкування, ставитися до неї як до цінності. Саме тому системна робота 3 сім'єю алкоголіка $\epsilon$ важливою складовою саме соціальної профілактики алкоголізму і його викоренення в людині.

На основі викладеного можна зробити такі висновки: в Україні існує потужна нормативна база для профілактики алкоголізму. Але питання соціальної профілактики алкоголізму не $\epsilon$ достатньо реалізованими, мають значний ресурс у вигляді 3 рівневої моделі соціальної профілактики, превентивного виховання в $3 \mathrm{CO}$ i 3BO, навчання життєвим умінням у вигляді навчальної програми для дітей від 1 до 11 класу, батьківської просвіти з проблеми, системної соціальнопрофілактичної роботи з сім'єю алкоголіка. Перспективами подальших досліджень є створення такої програми в системі $\mathrm{MOH}$ для ЗСО та їi апробація, координація всіх інформаційних заходів 3 первинної соціальної профілактики алкоголізму на рівні державної комплексноцільової програми. 
Вісник ЛНУ імені Тараса Шевченка № 1 (339), Ч. II, 2021

\section{Список використаної літератури}

1. В Україні спорт і пиво поєднають. Всеукраӥнська газета «Вісник». 2013. URL: http://archive.visnyk.lutsk.ua/2013/06/20/v-ukrajinisport-i-pyvo-pojednayut/ (дата звернення: 24.02.2021). 2. Воднік В. Проблеми профілактики алкоголізму в умовах побудови громадянського суспільства в Україні. Вісник Національного університету «Юридична академія України імені Ярослава Мудрого». 2014. № 3 (22). С. 239-255. 3. Глобальная стратегия сокращения вредного употребления алкоголя. ВО3, 2010. 40 с. 4. Закон України «Про державні цільові програми». URL: https://ips.ligazakon.net/document/t041621 ?an=\&ed=0000_00_00\& $\mathrm{dtm}=\& l e=$ (дата звернення: 26.02.2021). 5. Закон України «Про профілактику алкоголізму, наркоманії та токсикоманії». URL: https://ips.ligazakon.net/document/JF1OY00B?an=3 (дата звернення: 17.02.2021). 6. Котенко Т. Ю. Алкоголізм як соціальна проблема. Scientific researches and their practical application. Modern state and ways of development. URL: https://www.sworld.education/index.php/ru/ conference/the-content-of-conferences/archives-of-individual-conferences/oct2014 (дата звернення: 06.02.2021). 7. Максименко С. Д. Наркоманія: підходи до профілактики та подолання. Практична психологія та сойіальна робота. 2005. № 10. С. 1-3. 8. Минко О. І. Алкоголізм міждисциплінарна проблема (виявлення, лікування, реабілітація, профілактика). Український вісник психоневрологї. 2001. Т. 9. Вип. 4. С. 6-7. 9. Постанова Кабінету міністрів України «Питання проведення моніторингу наркотичної та алкогольної ситуації в Україні» від 10 липня 2019 p. URL: https://zakon.rada.gov.ua/laws/show/689-2019-\%D0\%BF\#Text (дата звернення: 20.01.2021). 10. Профілактична діяльність кримінальної міліції у справах неповнолітніх: методичні рекомендації. К., 2002. 44 с. 11. Розпорядження від 28 серпня 2013 р. «Про схвалення Стратегії державної політики щодо наркотиків на період до 2020 року». URL: https://www.kmu.gov.ua/npas/246715472 (дата звернення: 13.02.2021). 12. Сердюк О. О. Соціологічний аналіз динаміки та структури вживання алкоголю серед харків'ян (1959-1999 рр.). Вісник Національного університету внутрішніх справ. 2002. Вип. 18. С. 495499. 13. Трубавіна I., Каліна К., Данилюк I. Соціальна профілактика негативних явищ у молодіжному освітньому середовищі в аспекті використання здоров'язбережувальних технологій. Розвиток сучасной освіти і науки: результати, проблеми, перспективи. Т. 9: Синергія в розвитку науки та освіти. Конін [та ін.]: Посвіт, 2020. С. 149-151. 14. Закон України «Про соціальну роботу 3 сім'ями, дітьми та молоддю». URL: https://zakon.rada.gov.ua/laws/show/2558-14\#Tеxt (дата звернення: 26.02.2021). 15. Трубавіна I. М. Соціально-педагогічна робота з сім'єю: теорія та методика: монографія. Харків: «Нове слово», 2007. 395 c. 
Вісник ЛНУ імені Тараса Шевченка № 1 (339), Ч. II, 2021

\section{References}

1. V Ukraini sport i pyvo poiednaiut [In Ukraine, sports and beer will combine]. (2013). Vseukrainska hazeta «Visnyk» - All-Ukrainian newspaper «Visnyk». Retrieved from http://archive.visnyk.lutsk.ua/2013/06/20/v-ukrajinisport-i-pyvo-pojednayut/ [in Ukrainian]. 2. Vodnik, V. (2014). Problemy profilaktyky alkoholizmu $\mathrm{v}$ umovakh pobudovy hromadianskoho suspilstva $\mathrm{V}$ Ukraini [Problems of alcoholism prevention in the conditions of building civil society in Ukraine]. Visnyk Natsionalnoho universytetu «Iurydychna akademiia Ukrainy imeni Yaroslava Mudroho» - Bulletin of the National University «Yaroslav the Wise Law Academy of Ukraine», 3 (22), 239-255 [in Ukrainian]. 3. Hlobalnaia stratehyia sokrashchenyia vrednoho upotreblenyia alkoholia [Global strategy to reduce the harmful use of alcohol]. (2010). WOZ [in Russian]. 4. Zakon Ukrainy «Pro derzhavni tsilovi prohramy» [Law of Ukraine «On State Targeted Programs»]. Retrieved from https://ips.ligazakon.net/document/t041621?an=\&ed=0000_00_00\& $\mathrm{dtm}=\& \mathrm{le}=($ Last accessed 26.02.2021 $)$ [in Ukrainian]. 5. Zakon Ukrainy $«$ Pro profilaktyku alkoholizmu, narkomanii ta toksykomanii» [Law of Ukraine «On Prevention of Alcoholism, Drug Addiction and Addiction»]. Retrieved from https://ips.ligazakon.net/document/JF1OY00B?an=3 (Last accessed 17.02.2021) [in Ukrainian]. 6. Kotenko, T. Yu. (2014). Alkoholizm yak sotsialna problema [Alcoholism as a social problem]. Retrieved from https://www.sworld.education/index.php/ru/conference/the-content-of-

conferences/archives-of-individual-conferences/oct-2014 (Last accessed 06.02.2021) [in Ukrainian]. 7. Maksymenko, S. D. (2005). Narkomaniia: pidkhody do profilaktyky ta podolannia [Drug addiction: approaches to prevention and overcoming]. Praktychna psykholohiia ta sotsialna robota Practical Psychology and Social Work, 10, 1-3 [in Ukrainian]. 8. Mynko, O. I. (2001). Alkoholizm - mizhdystsyplinarna problema (vyiavlennia, likuvannia, reabilitatsiia, profilaktyka) [Alcoholism is an interdisciplinary problem (detection, treatment, rehabilitation, prevention)]. Ukrainskyi visnyk psykhonevrolohii - Ukrainian Bulletin of Psychoneurology, 9, 6-7 [in Ukrainian]. 9. Postanova Kabinetu ministriv Ukrainy «Pytannia provedennia monitorynhu narkotychnoi ta alkoholnoi sytuatsii v Ukraini» [Resolution of the Cabinet of Ministers of Ukraine «Issues of monitoring the drug and alcohol situation in Ukraine»]. (2019). Retrieved from https://zakon.rada.gov.ua/laws/show/689-2019-\%D0\%BF\#Text (Last accessed 20.01.2021) [in Ukrainian]. 10. Profilaktychna diialnist kryminalnoi militsii u spravakh nepovnolitnikh [Preventive activity of criminal police in cases of minors: methodical recommendations]. (2002). Kyiv [in Ukrainian]. 11. Rozporiadzhennia «Pro skhvalennia Stratehii derzhavnoi polityky shchodo narkotykiv na period do 2020 roku» [Order «On approval of the Strategy of the state policy on drugs for the period till 2020»]. (2013). Retrieved from https://www.kmu.gov.ua/npas/246715472 (Last accessed 13.02.2021) [in Ukrainian]. 12. Serdiuk, O. (2002). Sotsiolohichnyi analiz dynamiky ta struktury vzhyvannia alkoholiu sered kharkiv'ian (1959-1999 rr.) 


\section{Вісник ЛНУ імені Тараса Шевченка № 1 (339), Ч. II, 2021}

[Sociological analysis of the dynamics and structure of alcohol consumption among Kharkiv residents (1959-1999)]. Visnyk Natsionalnoho universytetu vnutrishnikh sprav - Bulletin of the National University of Internal Affairs, 18, 495-499 [in Ukrainian]. 13. Trubavina, I., Kalina, K., \& Danyliuk, I. (2020). Sotsialna profilaktyka nehatyvnykh yavyshch u molodizhnomu osvitnomu seredovyshchi v aspekti vykorystannia zdoroviazberezhuvalnykh tekhnolohii [Social prevention of negative phenomena in the youth educational environment in the aspect of use of health-preserving technologies]. Rozvytok suchasnoi osvity i nauky: rezultaty, problemy, perspektyvy - Development of modern education and science: results, problems, prospects. (Vol. 9), (pp. 149-151). Konin [etc.]: Posvit [in Ukrainian]. 14. Zakon Ukrainy «Pro sotsialnu robotu z sim'iamy, ditmy ta moloddiu» [Law of Ukraine «On Social Work with Families, Children and Youth»]. (2015). Retrieved from https://zakon.rada.gov.ua/laws/show/2558-14\#Text (Last accessed 26.02.2021) [in Ukrainian]. 15. Trubavina, I. (2007). Sotsialno-pedahohichna robota $\mathrm{z}$ sim'ieiu: teoriia ta metodyka [Socio-pedagogical work with the family: theory and methodology]. Kharkiv: «New word» [in Ukrainian].

Трубавіна І. М., Каліна К. Є. Соціальна профілактика алкоголізму серед молоді в Україні: перспективи та реалії сьогодення

Стаття присвячена актуальній проблемі - профілактиці алкоголізму серед молоді. Автори розкривають на основі теоретичного аналізу нормативної бази України i міжнародних документів 3 проблеми профілактики алкоголізму заходи, які зроблені і впроваджені в повсякденне життя українців, виділяють ресурси такої роботи серед соціальної профілактики серед дітей, молоді, сімей. Запропонована 3-рівнева система соціальної профілактики алкоголізму, показано призначення і групу впливу кожного рівня. Виділено ресурси соціальної профілактики у вигляді: роботи 3 мікро- i макросередовищем, превентивного виховання школярів i навчання їх життєвим умінням в закладах середньої освіти, системної соціальної роботи з сім'ями алкоголіків, методик укріплення сім'ї, мотивації до позбавлення цієї негативної звички. Перспективи подальших досліджень - розробка програми життєвих умінь з 1 по 11 клас, превентивне виховання школіряв, батьківський лекторий, системна робота з сім'єю.

Ключові слова: профілактика, соціальна профілактика, алкоголізм, укріплення сім'ї.

Трубавина И. Н., Калина К. Е. Социальная профилактика алкоголизма среди молодежи в Украине: перспективы и реалии сегодняшнего дня

Статья посвящена актуальной проблеме - профилактике алкоголизма среди детей и молодежи. Авторы раскрывают на основе теоретического анализа нормативной базы Украины и международных документов по проблеме профилактики алкоголизма мероприятия, которые сделаны и внедрены в повседневную жизнь украинцев, 


\section{Вісник ЛНУ імені Тараса Шевченка № 1 (339), Ч. II, 2021}

выделяют ресурсы такой работы среди социальной профилактики среди детей, молодежи, семей. Предложенная 3-уровневая система социальной профилактики алкоголизма, показано назначение и группу влияния каждого уровня. Выделены ресурсы социальной профилактики в виде: работы с микро- и макросредой, превентивного воспитания школьников и обучения их жизненным умениям в учреждениях среднего образования, системной социальной работы с семьями алкоголиков, методик укрепления семьи, мотивации к лишению этой негативной привычки. Перспективы дальнейших исследований - разработка программы жизненных умений с 1 по 11 класс, превентивное воспитание школьников, родительский лекторий, системная работа с семьей.

Ключевые слова: профилактика, социальная профилактика, алкоголизм, укрепление семьи.

\section{Trubavina I., Kalina K. Social Prevention of Alcoholism Among} Young People in Ukraine: Prospects and Realities of Today

The article is devoted to a topical issue - prevention of alcoholism among children, families and youth. The authors reveal on the basis of a theoretical analysis of the regulatory framework of Ukraine and international documents on the problem of alcoholism prevention measures that have been taken and implemented in the daily life of Ukrainians. In their article, the authors allocate new resources for such work among social prevention with children, youth, families.

The authors propose a 3-level system of social prevention of alcoholism, which shows the purpose and group of effects for each level. This is primary, secondary, tertiary social prevention. Primary social prevention requires information work among children, youth and their families. Secondary social prevention is dedicated to risk groups for alcoholism. Tertiary social prevention is aimed at working with those who already have this negative habit and their family members. For the first time in the theory of social work scientific approaches to social prevention of alcoholism among children, young people and their families are allocated: environmental, socialeducational, system, resource. This allowed the authors to identify new resources for social prevention of alcoholism among children, young people and their families in the form of: work with micro- and macro-environment, preventive education of schoolchildren and teaching their life skills in secondary education, systematic social work with families of alcoholics, family strengthening techniques, motivation to deprive this negative habit. Prospects for further research are: development of a curriculum for life skills of students in grades 1-11, preventive education for alcoholism, the state program for the prevention of alcoholism, parental lectures on alcoholism.

Key words: prevention, social prevention, alcoholism, family strengthening.

Стаття надійшла до редакції 13.02.2021 p.

Прийнято до друку 26.03.2021 р.

Рецензент - д. п. н., проф. Караман О. Л. 